文

$$
\begin{aligned}
\text { 鉄道車両の内装モジュール設計に対するリスク評価の応用 } \\
\text { 酒 井 信 介* 泉 聡志* } \\
\text { 横 山 喬** 牧 野 俊 昭*** }
\end{aligned}
$$

\title{
Application of Risk Assessment to Design of Interior Modules of Rolling Stocks
}

\author{
by \\ Shinsuke SaKaI ${ }^{*}$, Satoshi IzumI ${ }^{*}$, Takashi Yokoyama ${ }^{* *}$ and Toshiaki Makino ${ }^{* * *}$
}

In the design of railroad train, main interests have been placed on stiffness, mass and strength. Therefore, great improvement has been achieved in functional point of view. For further development, however, it is necessary to provide a procedure for the decision-making in design process. For example, if design change such as geometry variation or material replacement occurs, it is required to evaluate the validity of the action. For this purpose, a rational procedure to assist the decision-making is needed. However, the research from this point of view has not been done sufficiently so far.

In this paper, we attach importance to the decision-making performance in risk assessment. Though conventional risk assessment is used in the operational stage such as maintenance or inspection, it is investigated to apply the risk assessment in the design stage of railroad train. Specifically, the design of ceiling-shelf module is considered. By introducing the risk evaluation, not only the evaluation of function of single part but also the total performance for safety can easily be treated. Besides, uncertainty property is also able to be included in the assessment. After the formulation of risk assessment is stated, the application for several decision-making in ceiling-shelf module will be shown.

Key words : Risk assessment, Interior module, Sleeve-caulking fastening method, Decision-making, Design optimization

\section{1 緒言}

これまで，鉄道車両の設計にあたり，主に剛性，質量， 強度などの因子を主たる要素として, 改善が積み重ねら

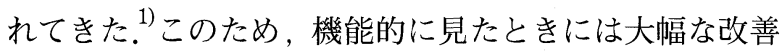
が行われたものと考えられるが，今後，さらなる改善を 進めるためには, 個別部品の構造変化や配置, 材料変更 などが派生して必要となるものと考えられる。攵の際， 最終的な決断をするにあたっての意思決定のための合理 的手段が必要である。.ところが，このような観点からの 研究は必ずしも十分に行われているとは言えない。

一方で，近年主に機械構造物の保守・検查においてり スク評価が意思決定手段のための手法として活用される ことが期待されており, ASME（米国機械学会）やAPI （米国石油学会）に打いては検查規格の策定が進行中で ある. ${ }^{2}$ この場合，検査間隔や検査範囲の合理的決定，新 規部品の交換に伴う妥当性の検証などにリスク評価が活 用されている。いずれも，機械製品が運用段階に入って からの, 合理化のためのリスク評価の活用ということが いえる．従来の Stress-Strength モデルによる評価の場合 には，評価対象が破損確率であったのに詨して，リスク 評価の場合にはこれに加えて破損時の影響度をも合わせ
て検討することに特徴がある。これにより，発生確率が 高く，なおかつ影響の大きな因子を抽出することが可能 となる。

本報に打いては, リスク評価の意思決定手段の機能を 重視し，鉄道車両の合理化への導入を検討する。ただし， 通常のリスク評価が運用段階で適用されるのに対して， ここでは設計段階での活用の可能性を検討する．対象と する構造は側天井・荷棚モジュールであり, 締結部の設 計の合理化を主題とする，荷棚モジュールは，製造工程 の短縮のためにはモジュール長の増大が望まれているも のの, 安全面から見た妥当性について検討が必要である. また，旧来のボルト締結に代わる新規締結方式（スリー ブかしめ締結）を導入した場合に，構造物全体にどのよ うな効果をもたらすか，などの評価も求められる。この ような評価を総合的に行うためには，締結部単体の機能 評価や，単純な応力解析のみでは不十分である。特に, 締結部の締結力に代表されるようにばらつきなどの不確 定性もとりいれた上で安全性評価を十分に行うことが困 難である.

リスク評価の場合，各締結部ごとに，その破損が全体 にどの程度の影響を与えるかの評価が可能であるため，

$\dagger$ 原稿受理 平成 14 年 4 月 10 日 Received Apr. 10,2002

* 正 会員 東京大学大学院工学系研究科機械工学専攻 ₹113-8656 東京都文京区本郷, Dept. of Mech., the Univ. of Tokyo, Bunkyo-ku,Tokyo, 113-8656

** 学生会員 東京大学大学院 干113-8656 東京都文京区本郷, Graduate Student, the Univ. of Tokyo, Bunkyo-ku,Tokyo, 113-8656

$* * *$ (株)日立製作所 $=744-8601$ 下松市大字東豊井, Hitachi, Ltd., Oaza Higasitoyoi, Kudamatu, 744-8601 
締結部に一対一に対応したリスクのランク付けが可能と なる。しかも，破損確率の評価を用いるために，強度と 荷重のばらつきを指標の中に反映できる。従って，安全 性を最適化するための，構造形状や締結部配直の意思決 定に活用できることが期待できる。本報では，車両の中 の側天井・荷棚モジュールについて，リスク定義を行い， 確率的有限要素法の併用によってリスク評価を行い, 構 造形状や締結部配置の意思決定手段にリスクを活用する ことの妥当性を検証する。

\section{2 解 析 対 象}

\section{2・1 側天井・荷棚モジュール}

従来, 鉄道車両の内装は部品単位で構体に取り付けら れていたが,リサイクル，リユースの観点から部品点数 削減，容易な着脱，リサイクル容易な材料の使用が求め られるようになった。この要求に応えるものの一つとし て, 内装の構造・機能・デザインの自立化を目的とした アルミ合金製の内装モジュールが開発された. ${ }^{1)}$ 内装モジ ユールは天井パネル，側天井・荷棚モジュール，側面パ ネルなどからなり (Fig. 1)，各々を外部で組み立てた後 構体に取り付けられる。構体には，長手方向に一様な断 面を持つ内装モジュール取り付け用レールが形成されて おり，ボルト等で内装モジュールが取り付けられる。本 研究では内装モジュールの一要素である側天井・荷棚モ ジュール (Fig. 1) を対象とし，その締結部のリスクを評 価する。

\section{$2 \cdot 2$ スリーブかしめ締結 ${ }^{3)}$}

従来，鉄道車两の内装や艤装の固定には小ねじによる 締結やボルト・ナット締結が広く用いられてきたが，締 結信頼性の向上，締結作業性の向上，メンテナンス容易 等の要求から, 従来の締結形式に代わる新締結としてス リーブかしめ蟐結が開発され採用されつつある.1)スリー ブかしめの構成を Fig. 2 に示す。クリンブのついたボル

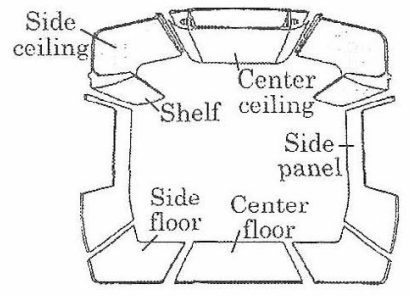

Cross Section

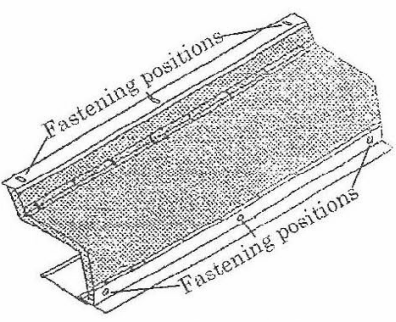

Ceiling-Shelf Module
Fig. 1. Interior Module.
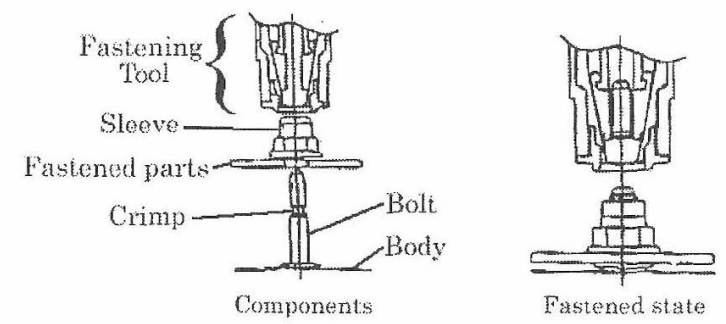

Fig. 2. Sleeve-Caulking Fastening Method."
トと雌ねじのないナット状のスリーブで棈成されており， 専用の工具を用いて締結する。締結工法は，ボルトを直 接工具で引つ張り，その反力で䧳ねじのないスリーブに ボルトをかしめ，ボルトねじ山に食いつかせて雌ねじを 成型し締結する工法である。この工法ではボルトを一定 荷重で破断させて締結するため, 工具の出力制御が不要 となり安定した締結力を得ることがでさる。また，従来 のボルト・ナット締結と異なり，ねじ山間に隙間がなく 塑性加工による残存応力が作用しているため，高い軸力 を得ることができる。從って, ボルト・ナット締結と比 較すると，大きな初期締結力が得られることおよび締結 力のばらつきを小さく抑えられることに特徴がある。し かし，これらの效果は必ずしも明確に定量的には示され ていない。そこで，ここでは新たにリスクを指標とした 評価を試みる。

\section{3 リスクに基づく内装モジュール設計 \\ $3 \cdot 1$ 問題の設定}

本研究では, 設計時点において側天井・荷棚モジュー ルの締結部に関してリスクを指標とした評価を行い，意 思決定手段に利用することの有效性を检証する。第一に， 内装モジュール技術の導入に伴って採用されたスリーブ かしめ締結の有効性の評価である。スリーブかしめ締結 は彷来のボルト・ナット締結と比較して締結力の平均值 が大きく，吕れにもかかわらず締結力のばらつきが小さ いという特徴を持っている。そこで，この 2 種類の締結 形式におけるそれらの違いがリスクの大きさに及ぼす影 響を検討する。第二に，現行のモジュールについて算出 したリスクを基準として，パネル長を現行の倍にした場 合の妥当性の検討と, 締結部配置の最適化について検討 する。

\section{$3 \cdot 2$ リスク定義}

通常，荷棚モジュールのような部品の締結部に関する 取り扱いは, 締結部単体の機能改善が検討されるととも に, 締結部の唒置は作業工程の容易さや見栄えなどが主 たる要因で決定されている。しかし，設計段階に沶いて， 締結部配置やパネル長について意思決定が求められると き, 構造体の山における各締結部が担う役割を的確に評 価することが求められる。その場合, 強度のばらつきや, 締結力のばらつきなどの不確定性因子についても配慮す る必要がある。これまでは，このような観点からの検討 は必ずしも十分に行わ机ているとは言えない。衤こで, ここでは新たにリスク概念を導入することしし，各締結 部のリスク值の評価により意思決定と結びつけることを 提案する。このためには，まず妥当性のあるリスクを定 義して打く必要がある。

工学リスクは一般的に, 機械やシステムの故障確率と その故障による被害の大きさの積として定義される。本 研究においては，モジュールにおける1箇所の締結部の 破損がモジュール全体の故障に至る可能性を評価する。 そこで、モジュールに拉けるある締結部の破損が他の締 結部に及ぼす影響を考えるために, 締結部 $i$ の破損確率 を $P_{i}$, 締結部 $i$ の破損が締結部 $j(\neq i)$ に及ぼす影響度 
を $C_{i j}$ として, 締結部 $i$ が締結部 $j$ に対して負うリスク $R_{i j}$, そして締結部 $i$ のリスク $R_{i}$ を以下のように定義する.

$$
\begin{aligned}
& R_{i j}=P_{i} \times C_{i j} \\
& R_{i}=\max _{j} R_{i j}
\end{aligned}
$$

以下で，上式における破損確率 $P_{i}$ および影響度 $C_{i j}$ を求 める手順を示す。

$\mathbf{3} \cdot \mathbf{2} \cdot \mathbf{1}$ 破損確率 締結部 $i$ の破損確率 $P_{i}$ を求める にあたり，側天井・荷棚モジュールに打ける荷重条件や 周囲の環境を考慮した上で，主たる要因として以下の 3 つの故障モードを考学る.

（1）過大荷重による締結部の破壊（破損確率 $P_{b}$ )

（2）繰り返し荷重による締結部の疲労破壊（破損確率 $\left.P_{f}\right)$

（3）締結物の回転緩み（破損確率 $P_{s}$ )

3 つの故障モードは独立で，同時に発生することはな いものと仮定する.すると, システムの信頼度は，3つ の破損モードの直列系で表現されるため,

$$
1-P_{i}=\left(1-P_{b}\right)\left(1-P_{f}\right)\left(1-P_{s}\right)
$$

であるが, $P_{b}, P_{f}, P_{s} \ll 1$ の場合, 近似式として $P_{i}$ は次 式で与えられる。

$$
P_{i} \approx P_{b}+P_{f}+P_{s}
$$

上述した故障モードに関係する材料值や締結力はばらつ きを持っているため，確率分布として考える必要がある. 本研究では, 材料值, 締結力等の入力值を確率分布とし て与え，ラテン方格サンプリングを用いたモンテカルロ 法により確率論的有限要素解析を行い, 故障モードの生 起確率に関係する出力値 (応力等) を求める. 出力值 (応力等) の確率密度関数 $f_{S}(x)$ と強度の確率密 度関数 $f_{R}(x)$ とから以下の式を用いて, 出力值 (応力) $>$ 強度となる確率すなわち故障確率を求める.

$$
P=\int_{0}^{\infty}\left\{\int_{0}^{x} f_{R}(\xi) d \xi\right\} f_{s}(x) d x
$$

材料值や構造形状等, 入力值について設定した確率分布 をTable Iに示す。確率分布は測定データが得られてい ないためすべて正規分布とし，変動係数 C. O. V. は安全 を見て大きめの值を設定した。ただし，2種類の初期締 結力分布は実験值に基づいて設定した，有限要素解析の

Table I. Scatter variable of Input Values. (Normal Distribution)

\begin{tabular}{|c|c|c|}
\hline Scatter Variables & C.O.V. & $\begin{array}{c}\text { Lower/Upper } \\
\text { Boundary }\end{array}$ \\
\hline \hline Young's Modulus & $5 \%$ & - \\
\hline Thickness of Panels & $5 \%$ & - \\
\hline Density & $5 \%$ & $99 \% / 101 \%$ \\
\hline $\begin{array}{c}\text { Initial Fastening Force } \\
\text { Bolt/Nut(mean=2.7kN) } \\
\text { Sleeve/Caulking(mean=3.3kN) }\end{array}$ & $13.0 \%$ & - \\
\hline $\begin{array}{c}\text { Coefficient of Static Friction be- } \\
\text { tween Fastener Head and Panel }\end{array}$ & $5 \%$ & - \\
\hline \hline Tensile Strength of Fastener & $5 \%$ & - \\
\hline Fatigue Strength of Fastener & $5 \%$ & - \\
\hline
\end{tabular}

繰り返し数は 1000 回とした。この計算に $\mathrm{CPU}$ 速度 $1.7 \mathrm{GHz} ， メ モ リ ー 512 \mathrm{MB}$ の計算機を使用して，1回の繰 り返し計算には $1600 \mathrm{~mm}$ のモデルで約 1 時間, $3200 \mathrm{~mm}$ のモデルで約 2 時間 30 分を要する. 以下で, 各故障モ 一ド生起確率の計算方法を説明する。

（1）過大荷重による締結部の破壊（破損確率 $P_{b}$ )

繰り返し有限要素解析を行った結果得られる, 締結物 を表現したビーム要素に発生する最大引張応力の確率分 布と, 締結物強度分布との相対的位置関係から破損確率 $P_{b}$ を求める.

（2）繰り返し荷重による締結部の疲労破壊（破損確 率 $P_{f}$ )

疲労損傷を評価するためには締結物に発生する引張応 力の応力振幅が必要であるが, 車両構造の場合, 応力振 幅が明確に求められていない場合が多い，そこで，(1)で 用いた締結物に発生する最大引張応力から応力振幅を推 定する方法が経験的に用いられている。この応力振幅の 確率分布と, 締結物瘦労強度分布との相対的位置関係か ら破損確率 $P_{f}$ を求める.

(3) 締結物の回転緩み（破損確率 $P_{s}$ )

回転緩みは被締結物が締結部座面に対して滑ることに より生ずると考える，そこで，回転緩みの生起確率 $P_{s}$ を, 被締結物が締結部座面に対して滑ろうとする力 $W$ の確率 分布と, 座面間摩擦力の確率分布とから求める.

$3 \cdot 2 \cdot 2$ 影響度 影響度 $C_{i j}$ は, 締結部 $i$ が故障する前 後での他の締結部 $j$ の故障確率の差で定義する。つまり，

$$
C_{i j}=P_{i j}-P_{j}
$$

故障前後の比ではなく差とすることで, $P_{i j}$ および $P_{j}$ の値 の絶対量を考虑することができる. 締結部 $i$ 故障後の締 結部 $j$ の故障確率 $P_{i j}$ を求めるためには締結部 $i$ のビーム 要素を省略したモデルを用いて $3 \cdot 2 \cdot 1$ 項で説明した方 法を実行した。

\section{$3 \cdot 3$ リスクに基づく意思決定法}

上記定義に基づいて, 各締結部ごとにリスク值を評価 する. 次に, リスク值の增減, リスクの適切配分などの 観点から妥当性を検討し，意思決定を行う。

\section{4 解 析モデル}

以下で，解析モデルとリスク計算手法を説明する.

\section{$4 \cdot 1$ 解析モデル}

Fig. 1 に相当する現行の側天井・荷棚モジュールの解 析モデルを Fig. 3 に示す. 解析コードはANSYS5.7 用 いる。このモデルは，シェル要素とビーム要素により構 成されている. 寸法を Fig. 4 に示す. 解析モデルの自由 度拘束条件について以下で説明する。

-上下パネル受け（Fig. 3 (b) 部) の構体と接する部 分は, 長手方向軸周りの回転を拘束している.

- 側天井パネルとパネル受けの接続部 (Fig. 3 (d) 部) は長手方向の全節点間をビーム要素で結合し，カップリ ング拘束を用いている.

・モジュールを構体に固定する締結物（Fig. 3 (e) 部) はすべてビーム要素で表現し，構体側の節点を全自由度 拘束する。モジュール側の節点はパネル受けを表現する 


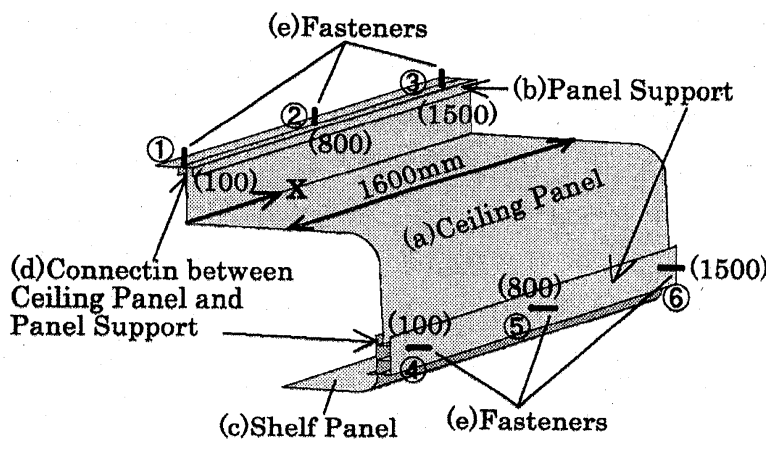

Fig. 3. An Analysis Model of Real Model (1) (6) are Fastener Numbers, () are x-coordinate of fastener).

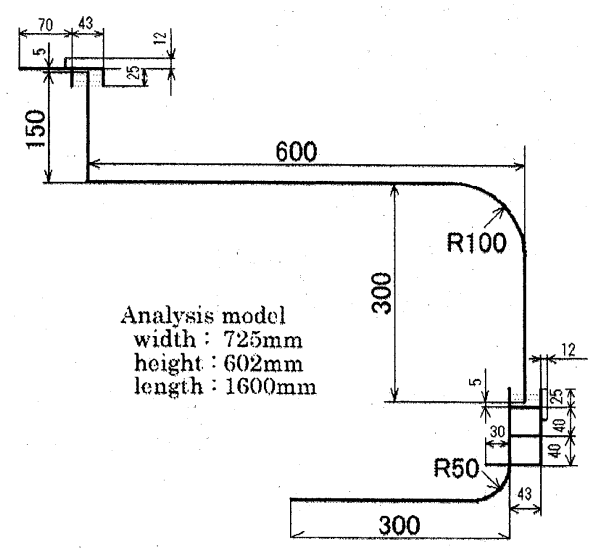

Fig. 4. Dimension of an Analysis Model.

シェル要素の節点との共通節点としている.

次に荷重条件について説明する.

- 実物実験時の条件に従って, 荷棚先端に $1.96 \mathrm{kN} / \mathrm{m}$ $(3.14 \mathrm{kN} / 1.6 \mathrm{~m})$ の等分布荷重を作用させた，荷重を作用 させる位置に関しても実験時の条件に合わせて，両端 2 箇所に $392 \mathrm{~N}$ ，中央 3 箇所に $784 \mathrm{~N}$ の集中荷重を作用さ せた。

・締結部を表現したビーム要素とシェル要素の共通節 点には初期締結力に相当する引張荷重を作用させた。

- 重力加速度を作用させた。

\section{$4 \cdot 2$ 評価対象モデル}

計算に用いたモデルの一覧を Table II に示す．各モデ ルの締結位置に関しては評価を行う節で示す。モデル 1 は Fig. 3 に示す現行のモデルである。長さ $1600 \mathrm{~mm}$ で 上下 3 筒所ずつのスリーブかしめ締結部を持つ。モデル

Table II . Models that are assessed in this study.

\begin{tabular}{|c|c|c|c|}
\hline Model & $\begin{array}{c}\text { Length } \\
{[\mathrm{mm}]}\end{array}$ & $\begin{array}{c}\text { Fastening } \\
\text { Type }\end{array}$ & $\begin{array}{c}\text { Fastener } \\
\text { Upper/Lower }\end{array}$ \\
\hline \hline 1 & 1600 & S/C & $3 / 3$ \\
\hline 2 & 1600 & B/N & $3 / 3$ \\
\hline 3 & 3200 & S/C & $3 / 6$ \\
\hline 4 & 1600 & B/N & $2 / 4$ \\
\hline 5 & 1600 & B/N & $2 / 4$ \\
\hline 6 & 3200 & S/C & $3 / 6$ \\
\hline
\end{tabular}

2 は締結形式によるリスクの違いを調べるための比較モ デルで，モデル 1 において締結部をボルト・ナット締結 とした。モデル 3 は，新しいモジュールとして実用化が 検討されている, Fig. 5 に示す長さ $3200 \mathrm{~mm}$ のモデルで ある，締結位置は $1600 \mathrm{~mm}$ の場合の延長とし，スリーブ かしめ締結部を上側 3 箇所, 下側 6 箇所 (等間隔) とし た，モデル 4，5 は 1600mmのモデルにおいて締結位置 の違いによるリスクの変化を調べるために作成したモデ ルである，長さ $1600 \mathrm{~mm}$ で上側 2 箇所，下側 4 箇所の締 結部を持つ。モデル 4 と 5 では, 下側締結部の締結間隔 を異なるものとしている. モデル 6 は $3200 \mathrm{~mm}$ のモデル において締結位置最適化を行った結果得られたモデルで ある。

\section{5 解 析 結 果 \\ $5 \cdot 1$ 実用化モジュールのリスク}

モデル 1 について評価を行った結果を Table III に示す。 Table III (a) は各締結部のリスク $R_{i}$ である。これより, 上側締結部（1)～(3)）ではリスク $R_{i}$ はほぼ 0 となり，作 用する荷重の大部分は下側締結部 (4)～(6)）が負担して いることが分かった. 特にモジュ一ル両端の締結部(4)(6) のリスクが $R_{i}=2.59 \times 10^{-8}$, モジュール中央の締結部(5) のリスクが $R_{i}=6.56 \times 10^{-4}$ となっており，下側中央締結 部が大きなリスクを負っていることが分かった。また， Table III (b) はモデル 1 において締結部の故障がない状 態で, $3 \cdot 2 \cdot 1$ 項に示す各故障モードの破損確率を示し たものである. 故障モードの番号は $3 \cdot 2 \cdot 1$ 項に示した ものに対応する。これより, 最も生起確率の高い故障モ

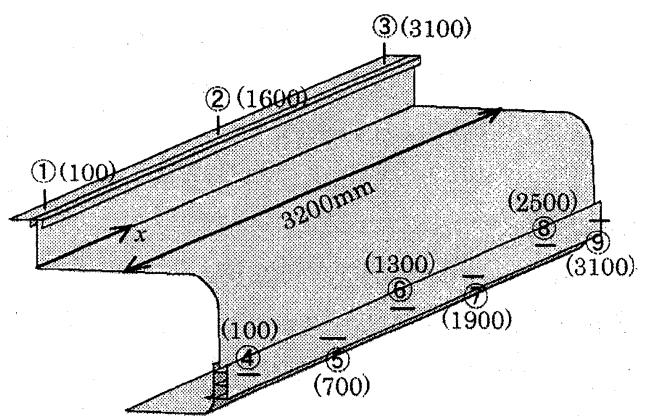

Fig. 5. A 3200mm Model with 9 Fasteners (Model 3).

Table III. Result of the assessment of Model 1. (S/C : Sleeve/ Caulking Fastening)

(a) Risk of Fasteners

\begin{tabular}{|c|c|c|ccc|}
\hline Model & $\begin{array}{c}\text { Length } \\
{[\mathrm{mm}]}\end{array}$ & $\begin{array}{c}\text { Fastening } \\
\text { Type }\end{array}$ & \multicolumn{3}{|c|}{ Risk of Fasteners } \\
\cline { 3 - 6 } & (1)(2)(3) & (4)(6) & (5) \\
\hline 1 & 1600 & $\mathrm{~S} / \mathrm{C}$ & $\sim 0$ & $2.59 \mathrm{E}-08$ & $6.56 \mathrm{E}-04$ \\
\hline
\end{tabular}

(b) Failure Probability of Model 1

\begin{tabular}{|c|c|c|c|ccc|}
\hline Model & Length & Fastening & Failure & \multicolumn{4}{|c|}{ Failure Probability } \\
\cline { 4 - 6 } & {$[\mathrm{mm}]$} & Type & mode & (1)(2)(3) & (4)(6) & (5) \\
\hline & & & $(\mathbf{1})$ & $\sim 0$ & $\sim 0$ & $\sim 0$ \\
1 & 1600 & $\mathrm{~S} / \mathrm{C}$ & $(\mathbf{2})$ & $\sim 0$ & $\sim 0$ & $\sim 0$ \\
& & & $(3)$ & $\sim 0$ & $1.12 \mathrm{E}-01$ & $4.94 \mathrm{E}-01$ \\
\hline
\end{tabular}


ードは (3) 締結物の回転緩みであることが分かる.1箇 所の締結物が故障した状態で解析を行った結果も同様の 傾向を示したことから, リスク $R_{i}$ に対して最も大きな寄 与をするのは締結部の回転ゆるみである.

実物試験では，このモジュールを用いることにより十 分な安全が得られることが実証されている. 従って, 以 後，モデル 1 のリスク $R_{i}$ を基準として考えることにする.

\section{$5 \cdot 2$ スリーブかしめ締結の効果}

ボルト・ナット締結を用いた場合と比較して，スリー ブかしめ締結を用いることによりリスクをどの程度削減 することができたのかを調べるために，モデル 1 におい て締結部をボルト・ナット締結としたモデル 2 について 評価を行った. Table IVに示すモデル 2 の結果を Table IIIのモデル 1 の結果と比較すると，上側締結部（1)～(3) に関してはリスク $R_{i}$ はほぼ 0 に抑えられているが，下側 締結部（4)〜 (6)）に関してはリスク $R_{i}$ は $10^{-1}$ オーダー と非常に大きな值となっている，従って，スリーブかし め締結を用いることによるリスク $R_{i}$ 削減効果は大きいと 考えられる.

\section{$5 \cdot 3$ モジュール長さ $3200 \mathrm{~mm}$ のモジュール}

モデル 3 の形状を Fig. 5 に示す. Table Vに示す結果 より，下側締結部に関して両端の締結部(4)(9) と中央の締 結部(6)(7)の間でリスク $R_{i}$ に大きな差が見られる。また， 下側締結間隔が $700 \mathrm{~mm}$ であるモデル 1 の最大リスクが $6.56 \times 10^{-4}$ である一方で, 下側締結間隔 $600 \mathrm{~mm}$ である モデル 3 の最大リスクが $1.38 \times 10^{-3}$ であることから, モ デル 3 はモデル 1 よりも締結間隔が小さいにもかかわら ず最大リスクは大きくなっている，従って，モデル 3 に 関しては下側各締結部間でのリスク $R_{i}$ の差が小さくなる ように, 締結位置の改善が必要であると考えられる.

\section{6 考 察}

リスク的取り扱いにより，リスク低減効果に対する感 度分析や締結部配置の最適化が可能であるので, 意思決 定のための副次的情報を得ることができる.

\section{$6 \cdot 1$ スリーブかしめ締結の効果}

$5 \cdot 2$ 節の結果よりスリーブかしめ締結を採用すること に対する効果をリスク評価により定量的に示し得ること を明らかにしたが，さらに，この効果が何に起因するの かを明らかにできれば，意思決定を補強するための有用 な情報となることが考えられる。ここでは，リスク削減

Table IN . Risks of $1600 \mathrm{~mm}$ Bolt/Nut Fastening (B/N) Model.

\begin{tabular}{|c|c|c|ccc|}
\hline Model & Length & Fastening & \multicolumn{3}{|c|}{ Risk of Fasteners } \\
\cline { 4 - 6 } & {$[\mathrm{mm}]$} & Type & (1)(2)(3) & (4)6 & (5) \\
\hline 2 & 1600 & $\mathrm{~B} / \mathrm{N}$ & $\sim 0$ & $1.69 \mathrm{E}-01$ & $4.35 \mathrm{E}-01$ \\
\hline
\end{tabular}

Table V. Risks of a 3200mm Model. (Model 3)

\begin{tabular}{|c|c|c|cccc|}
\hline \multirow{2}{*}{ Model } & Length & Fastening & \multicolumn{4}{|c|}{ Risk of Fasteners } \\
\cline { 4 - 7 } & {$[\mathrm{mm}]$} & Type & (1)(2)(3) & (4)(9) & (5)(8) & (6)(7) \\
\hline 3 & 3200 & $\mathrm{~S} / \mathrm{C}$ & $\sim 0$ & $\sim 0$ & $2.33 \mathrm{E}-05$ & $1.38 \mathrm{E}-03$ \\
\hline
\end{tabular}

効果に対して分布の平均值と変動係数のどちらの違いに よる影響が大きいのかを調べるために, Fig. 3 のモデル の下側締結部について感度解析を行った.7 まず，因子 A を平均值, 因子 B を変動係数として, Table Vに示すよ うに因子 $\mathrm{A}$ を 3 水準，因子 $\mathrm{B}$ を 5 水準設定し，各組み 合わせについてリスク計算を行った．水準数は有意な結 果が得られる程度の数を選び，水準值はできる限り等間 隔になるように設定した，次に得られた結果を用いてリ スク $R_{i}$ に対する 2 因子の感度解析を行った. その結果を Table VII示す. 締結部(4)(6)締結部(5)とでは, リスク 削減に対する影響が大きい因子が異なることが分かる。 また，今回行ったのは実験ではなく解析であるため，締 結力の平均值と標準偏差以外のパラメータはすべて完全 に固定されている。それ故，他にリスクを変動させる因 子はないので, Table VII の残差 e は因子 A と因子 B の相 互作用を表現することになる。よって, Table UII示し た寄与率はすべて有意な值であると考えられる.

\section{6・2 締結位置によるリスク変化}

6・2・1 解析結果 モデル 1,2 では下側中央の締結 部にリスクが集中しているため，その部分に対策を施す ことで，下側締結部のリスクを均等化することができる ものと考えられる。同時に, リスクの小さい上側に関し ては締結数の削減が可能であると考えられる。ここで， 締結部を増加させる位置によるリスク削減効果の違いを 調べるために，長さ $1600 \mathrm{~mm}$ のモジュールにおいてボル ト・ナット締結部を上側 2 本，下側 4 本とした締結間隔 の異なる 2 種類のモデル（モデル 4, 5 ； Fig. 6）につ いて評価を行った。モデル 5 はモデル 4 と比較して締結 部(4)(5)をモジュール中央寄りとした. Table VIIIに示すモ デル 4 の結果では，最大リスクは $10^{-2}$ オーダーとなって いるのに対し，モデル 5 の結果では，最大リスクは $10^{-3}$ オーダーとなっており，下側締結部間のリスク $R_{i}$ 差も小 さく抑えられている. 従って, 締結数を据え置いても,

Table VI. Two Levels of Two Factors.
Factor A

Mean of Fastening Force

\begin{tabular}{|c|l|}
\hline Level & Value[kN] \\
\hline \hline A1 & $2.7(\mathrm{~B} / \mathrm{N}$ mean $)$ \\
$\mathrm{A} 2$ & 3.0 \\
$\mathrm{~A} 3$ & $3.3(\mathrm{~S} / \mathrm{C}$ mean $)$ \\
\hline
\end{tabular}

Table VII. Contribution rate of mean and C.O.V. of the fastening force to risk.

(a)Fastener(4)(6)

\begin{tabular}{|c|c|}
\hline Factor & Contribution \\
\hline \hline Factor A & $25.7 \%$ \\
Factor B & $54.7 \%$ \\
Residual e & $19.6 \%$ \\
\hline
\end{tabular}

(b)Fastener(5)

\begin{tabular}{|c|c|}
\hline Factor & Contribution \\
\hline \hline Factor A & $62.8 \%$ \\
Factor B & $9.8 \%$ \\
Residual e & $27.4 \%$ \\
\hline
\end{tabular}

\begin{tabular}{|c|l|}
\hline Level & \multicolumn{1}{|c|}{ Value[\%] } \\
\hline \hline B1 & $13.0(B /$ N C.O.V.) \\
B2 & 10.5 \\
B3 & 8.1 \\
B4 & 5.4 \\
B5 & 2.7 (S/C C.O.V.) \\
\hline
\end{tabular}




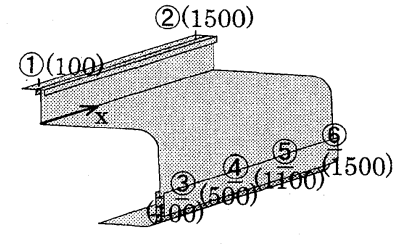

Model 4

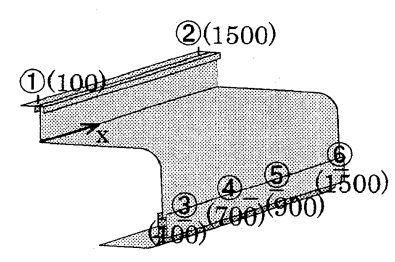

Model 5
Fig. 6. Two Models Different in Lower Fastening Positions.

Table VII. Difference in Risks by the Fastening Positions with Non-Optimized and Optimized Fastening Position.

\begin{tabular}{|c|c|c|ccc|}
\hline \multirow{2}{*}{ Model } & \multirow{2}{*}{$\begin{array}{c}\text { Length } \\
{[\mathrm{mm}]}\end{array}$} & Fastening & \multicolumn{3}{|c|}{ Risk of Fasteners } \\
\cline { 4 - 6 } & & Type & (1)(2) & (3)6 & (4)(5) \\
\hline 4 & \multirow{2}{*}{1600} & \multirow{2}{*}{$\mathrm{B} / \mathrm{N}$} & $\sim 0$ & $2.39 \mathrm{E}-03$ & $1.55 \mathrm{E}-02$ \\
\cline { 4 - 6 } & & & $\sim 0$ & $6.92 \mathrm{E}-03$ & $5.30 \mathrm{E}-03$ \\
\hline
\end{tabular}

下側中央部に締結部を集中させることにより，効果的に リスクを小さくできることが分かった．また，モデル 4 ， 5 において締結部をスリーブかしめ締結としたモデルに ついても評価を行ったところ, 同様にモデル 5 の締結位 置でのリスクの方が小さいという結果となったが，どちら の締結位置に打いてもリスクは $10^{-10}$ 以下となり，モデル 1 と比較するとはるかに安全であるという結果となった.

$6 \cdot 2 \cdot 2$ リスクに影響を及ぼすパラメータ $5 \cdot 1$ 節 において述べたように, 本研究において行った解析結果 において, 考慮に入れる 3 つの故障モードのうち, リス クに最も大きな影響を及ぼすのは締結部の回転緩みの生 起確率であった。ここで, 回転緩みの生起確率の計算に 用いる 2 つのパラメータ（被締結物並進力 $W$, 座面間摩 擦力 $\left.F_{f}\right)$ のうちどちらの分布がリスクに対して大きな影 響を及ぼすのかを考える。モデル 4,5 について，W， $F_{f}$ の平均值と C. O. V.およびリスク $R_{i}$ を表にしたものを Table IXに示す。これより, リスク $R_{i}$ に対して最も大き な影響を及ぼすパラメータは被締結物並進力 $W$ の平均值 であることが分かった。すなわち, 被締結物の並進力 $W$ の平均値とリスクは正の相関関係にあると予測できる. $W$ 平均值は, すべての入力パラメータをその平均值に 固定して静解析を 1 回行った結果得られる $W$ の值にほほ

Table IX. The Relation between Risk and the Parameters that relates to Failure Probability of Failure Mode (3).

(a) The Case of Model 4

\begin{tabular}{|c|c|c|c|c|c|}
\hline Fastener & $\begin{array}{c}F_{f} \text { mean } \\
{[\mathrm{N}]}\end{array}$ & $\begin{array}{c}F_{f} \text { C.O.V. } \\
{[\%]}\end{array}$ & $\begin{array}{c}W \text { mean } \\
{[\mathrm{N}]}\end{array}$ & $\begin{array}{c}W \text { C.O.V } \\
{[\%]}\end{array}$ & Risk \\
\hline \hline (3)(6) & 402 & 14 & 243 & 1 & $2.39 \mathrm{E}-03$ \\
\hline (4)(5) & 410 & 14 & 295 & 1 & $1.55 \mathrm{E}-02$ \\
\hline
\end{tabular}

(b) The Case of Model 5

\begin{tabular}{|c|c|c|c|c|c|}
\hline Fastener & $\begin{array}{c}F f \text { mean } \\
{[\mathrm{N}]}\end{array}$ & $\begin{array}{c}F_{f} \text { C.O.V.V } \\
{[\%]}\end{array}$ & $\begin{array}{c}W \text { mean } \\
{[\mathrm{N}]}\end{array}$ & $\begin{array}{c}W \text { C.O.V } \\
{[\%]}\end{array}$ & Risk \\
\hline \hline (3)(6) & 404 & 14 & 277 & 1 & $6.92 \mathrm{E}-03$ \\
\hline (4)(5) & 409 & 14 & 262 & 1 & $5.30 \mathrm{E}-03$ \\
\hline
\end{tabular}

等しい. 従って，この場合，静解析を 1 回行った結果得 られる被締結物並進力 $W$ をパラメータとしてリスク $R_{i}$ を最適化することができると考えられる。

\section{$6 \cdot 3$ 締結位置によるリスク变化 $(3200 \mathrm{~mm})$}

$\mathbf{6} \cdot \mathbf{3} \cdot \mathbf{1}$ 締結位置最適化 $\mathbf{5} \cdot \mathbf{3}$ 節の結果より, 3200 $\mathrm{mm}$ のモデルにおいて $1600 \mathrm{~mm}$ のモデルと同様に締結位 置を等間隔に設定したのでは各締結部間でのリスク差が 大きくなってしまうことが分かった。しかし，6・2節に おいて，1600mmのモデルに関して適切な締結位置を選 択することによってリスクを抑えることができることが 分かった．従って，3200mm のモデルに打いても適切な 締結位置を選ぶことにより，リスクを抑えることができ ると考えられる。

ここでは, $6 \cdot 2 \cdot 2$ 項の考察に基づいて, 静解析を 1 回行った結果得られる被締結物並進力 $W$ をパラメータと してリスク最適化を行い, 最適な締結位置を設定する. 本来, 締結位置の設定を行うにあたっては, リスクにつ いて最適化を行うべきであると考えられるが，最適值の 探索段階でリスク解析を行うことは, 膨大な計算時間を 要し, 実用的でない. そこで, リスクと相関のある $W に$ 着目して，おおよそ最適化した後に，リスクによる詳細 な検討を行うこととする.

そこで, 3200mm のモデルの下側締結部に注目し，1 回の静解析を行った結果得られる被締結物並進力 $W に$ ついて，下側各締結部においてその最大值と最小值の差 を最小化することを考える. $3200 \mathrm{~mm}$ のモデルについて 両端の締結位置は固定し, 締結位置の対称性を保った上 でその他の締結位置を $100 \mathrm{~mm}$ 単位で変化させて静解析 を行った (Fig. 7). 条件より, 変化させるパラメータは 2 箇所の締結位置 $\left(x=x_{1}, x_{2}\right)$ である. その結果，被締結物 並進力 $W$ の差が最も小さくなるのは $x_{1}=1100 \mathrm{~mm}, x_{2}=$ $1200 \mathrm{~mm}$ としたときであった。 そこで，この締結位置を 設定したモデル（モデル 6) についてリスク計算を行っ た. Table X に示すリスク $R_{i}$ をモデル 3 のリスク $R_{i}$ (Table V) と比較するとリスク均等化を達成できたこと が分かる。しかし，依然として下側締結部が荷棚荷重の 大部分を負担している状態である。上側締結部にも下側 締結部と同様に荷重を負担させることができれば，下側 締結本数をさらに減少させることができるはずである.

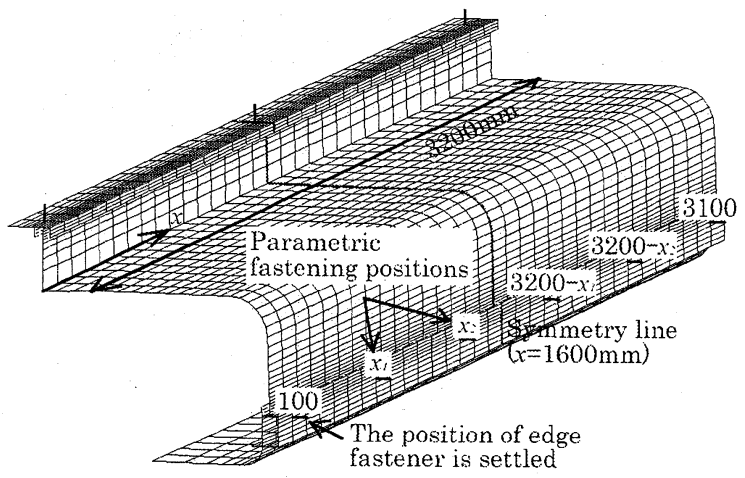

Fig. 7. The Condition of Optimizing Fastening Positions. 
Table X . Risks of Optimized 3200mm Model.

\begin{tabular}{|c|c|c|cccc|}
\hline Model & $\begin{array}{c}\text { Length } \\
{[\mathrm{mm}]}\end{array}$ & $\begin{array}{c}\text { Fastening } \\
\text { Type }\end{array}$ & \multicolumn{4}{|c|}{ Risk of Fasteners } \\
\hline 6 & 3200 & S/C & $\sim 0$ & $9.27 \mathrm{E}-06$ & $2.14 \mathrm{E}-06$ & $8.58 \mathrm{E}-07$ \\
\hline
\end{tabular}

それには締結本数や位置の変更だけでは不可能であり， 構造上の変更が必要であると考えられる.

$6 \cdot 3 \cdot 2$ 最適化の検証 $6 \cdot 3 \cdot 1$ 項に括いては，2箇 所の締結位置を $100 \mathrm{~mm}$ 単位で変化させ繰り返し静解析 を行うことによってリスク均等化を図った。ここで，最 適な位置として設定した位置 $\left(x_{1}=1100 \mathrm{~mm}, x_{2}=\right.$ $1200 \mathrm{~mm})$ の周辺について, 変化の傾向と最適位置に関 して, 実験計画法を用いて調べる.7 2 箇所の締結部中点 座標 $\left(x_{1}+x_{2}\right) / 2$ を因子 $\mathrm{A}, 2$ 箇所の締結部の間隔 $x_{2}-x_{1}$ を因子 $\mathrm{B}$ として，リスク $R_{i}$ に対する 2 因子の感度解析 を行う，各因子の水準を Table XI のように設定した，感 度解析を行った結果を Table XII に示す。また，下側締 結部における被締結物並進力 $W$ の差に対する因子 $\mathrm{A} ， \mathrm{~B}$ の区間推定 Fig. 8 に示す. Table XII に結果を示す通 り, 設定した $2 つ の$ 因子のうち, 因子A（締結部の $x$ 座 標の平均值）がリスクに対して感度が高いことが分かっ た。 また, 締結部の間隔はリスクに対して感度が低いが， Fig. 8 に示す区間推定結果より締結部の間隔が小さい方 がリスクが小さくなることが分かる，さらに，Fig，8の 因子 $\mathrm{A}$ の結果より, 締結部の $x$ 座標の平均值が $1100 \mathrm{~mm}$ 付近であるとき下側締結部に捛ける被締結物並進力 $W$ の 差は最小になることが分かる、ここで, $1100 \mathrm{~mm}$ という 值は両端の締結部間を 3 等分した位置である. 従って, 下側締結部を 6 筒所設定する場合，モジュール両端に 1 箇所ずつとその 3 等分点に 2 籄所ずつ設定するのが望ま しいことが分かる。

\section{7 結}

\section{言}

設計時にリスク評価を導入することにより，合理化が 達成できることの見通しを得た，以下に結論を要約する，

(1) 旧来のボルト・ナット縍結に対して，スリーブか しめ締結がリスクの観点から合理的であることを明らか にした，リスク削減効果には，締結力の平均值と分散が

Table XI . Settings of Level Values of Two Factors.

\begin{tabular}{|c|c|}
\hline \multicolumn{2}{|c|}{ Factor A } \\
\hline \hline Level & Value[mm] \\
\hline A1 & 950 \\
A2 & 1050 \\
A3 & 1150 \\
A4 & 1250 \\
\hline \hline Level & Value[mm] \\
\hline B1 & 200 \\
B2 & 400 \\
B3 & 600 \\
\hline
\end{tabular}

Table XII . Contributions of Fastening Positions to Risk.

\begin{tabular}{|c|c|}
\hline Factor & Contribution \\
\hline \hline Factor A & $88.5 \%$ \\
Factor B & $10.2 \%$ \\
Residual e & $1.3 \%$ \\
\hline
\end{tabular}

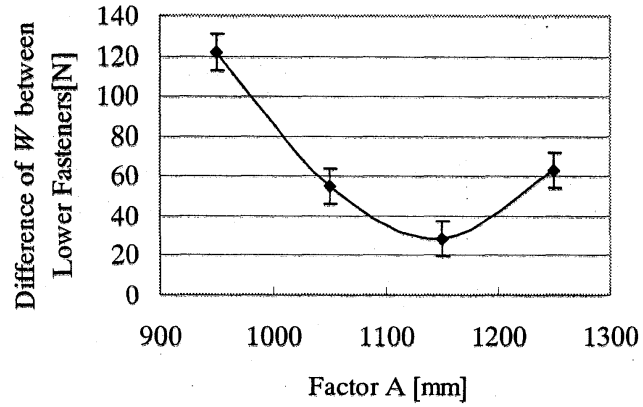

(a) Factor $\mathrm{A}$

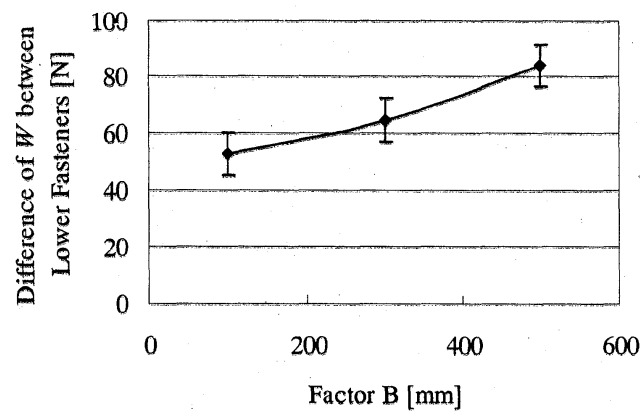

(b) Factor $B$

Fig. 8. Interval Estimation of W to Two Factors.

影響するが，その効果は締結位置によって異なることを 実験計画法を用いて明らかにした。

（2）適切な締結位置を設定することにより，リスクを 抑えることができる，3200mmのモデルについて，リス クと相関の強いことが分かった被締結物並進力について 最適化を行ったところ，リスクの均等化を達成すること ができ，現在用いられているモジュールよりも低いリス クに抑えることができた，その結果モジュール点数で $1 / 2$ ， 締結数で $1 / 4$ 削減可能となることを明らかにした。

(3) $3200 \mathrm{~mm}$ のモデルの最適な締結位置について実験 計画法を用いて検討を行った。 その結果, リスクを低減 させるための最適配置の決定に応用できることを示した。

以上のように，車両の設計段階にリスク的取り扱いを 導入することにより，新工法の妥当性評価や，形状変更 の影響の見積もり，締結部配置など，重要な意思決定に 活用できることを示した。

\section{参 考 文 献}

1) 奥野澄生, 高井英夫, 戸取征二郎, 川崎 健, 機械の研 究, 53, 144 (2001).

2) 小林英男, 材料科学, 37, 171 (2000).

3) 小川達也, 谷川 修, 加藤 亭, 自動車技術, 50(12), 49 (1996).

4) 吉本 勇, “JIS 使い方シリーズ ねじ締結体設計のポイン ト”, p.119（1992）日本規格協会.

5）(踭アンシスジャパン, ANSYS Conference in Japan 2001 会 議資料, 109 (2001).

6) 日本材料学会編，“機械・構造系技術者のための実用信頼 性工学", p.143（1987）養賢堂.

7）中村義作，“よく分かる実験計画法”, p.19（1997）近代科 学社. 